\title{
ONLINE REKLÁMOK: TARTALMI SAJÁTOSSÁGOK ÉS HATÁSUK A FOGYASZTÓKRA
}

\section{ONLINE ADVERTISING: CONTENT PARTICULARITIES AND CONSUMER EFFECTS}

\author{
Zsigmond István* \\ ${ }^{1}$ Alapismereti és Szakmódszertani Tanszék, Pedagógusképző Kar, Neumann János Egyetem, \\ Magyarország \\ https://doi.org/10.47833/2020.1.ART.003
}

\section{Kulcsszavak: \\ online reklám \\ pozicionálás \\ fogyasztói attitüd}

\section{Keywords:}

online advertising

positioning

consumer behaviour

\section{Cikktörténet:}

Beérkezett 2019. október 1.

Átdolgozva 2019. december 16.

Elfogadva 2019. december 22.

\begin{abstract}
Összefoglalás
Az internet megjelenésével egyre nagyobb szerepet kapnak az online reklámok. Az online felület olyan lehetöséget biztosit a reklám számára, amely jelentős mértékben megváltoztathatja a reklámkészítési és fogyasztási szokásokat; tulajdonképpen a reklámtevékenység egy új korszakába léptünk.

A változóban levő fogyasztói magatartás következtében a marketingkommunikációs stratégiák tervezésekor egyre inkább szükségessé válik az egyedi reklámötletre, és többnyire emocionális pozícionálásra építő stratégiák helyett a funkcionális pozicionálás, a termékinformációkat előtérbe helyező üzenetek közvetítése.
\end{abstract}

\begin{abstract}
The Internet is not just a new type of advertising media, but a tool facilitating paradigmatic changes in the advertising industry.

The article presents some basic characteristics of online advertising and their possible effects on advertising strategies and changes in consumer behaviour.
\end{abstract}

\section{Reklám az interneten}

Az internet kezdetben katonai céllal jött létre - egy olyan hálózat létrehozása volt a cél, amelynek egyes csomópontjai megsemmisülése esetén is lehet információt továbbítani elektronikus eszközökkel. Késöbb a technológia publikussá válásának célja az volt, hogy szabadon hozzá lehessen férni különböző adatokhoz, elsősorban kutatási és kormányzati célokból. A hálózat fokozatosan a kereskedelem szolgálatába szegődött. A vállalkozások hamar felismerték, hogy az internet igen jó lehetőséget biztosít az önmagukról való információközlésre, valamint az ügyfelekkel való kapcsolattartásra, ezért bekerült a promóciós tevékenységek eszköztárába. Az internet egyik elönye más médiumokkal szemben az, hogy nagyszámú, és igen változatos információ elérését tesz gyorsan lehetővé.

$A z$ online reklámozás kezdetben egy szervezet vagy termék honlapjának létrehozására korlátozódott. Később megjelentek a kifejezetten reklámozási célú szövegek és hirdetési felületek (szalaghirdetések; nyomógombok; szöveges linkek; beférkőző reklámok, stb.). Céljuk, hogy a hirdető oldalára csalogassák az olvasót. Ezek kezdetben a hagyományos reklámok mintájára

\footnotetext{
* Kapcsolattartó szerző. E-mail cím: zsigmond.istvan@pk.uni-neumann.hu
} 
készültek, késöbb azonban egyre változatosabb formákat vettek fel, és egyre nagyobb felületeket foglaltak el [1].

$\mathrm{Az}$ internetes kommunikáció már az életünk része, a munkahelyi és a magánjellegü kommunikációban is jelentős szerepe van. A vásárlók egyre többet töltenek az interneten, amely egyre nagyobb forgalmat generál az online reklám világában. Egy igen gyorsan fejlődő reklámozási formáról van szó. Az internet-felhasználók ugyanolyan természetesnek veszik a reklámokat a világhálón, mint a többi médium esetében [1]. Ezért a számítógép-képernyők, valamint a mobiltelefonok képernyői váltak a világ legértékesebb reklámfelületévé.

\section{Szemléletmódváltás az online reklámokban}

\subsection{Az online és hagyományos reklámok összehasonlítása}

Az internetes reklámozás számos vonatkozásban különbözik a hagyományos médiafelületeken történő reklámozástól. Célunk a későbbiekben rámutatni arra, hogy ez jelentősen befolyásolhatja a marketingkommunikációs stratégiák tervezését, az ugyancsak változó fogyasztói elvárásoknak és magatartásnak megfelelően. A továbbiakban felsorolunk néhányat ezek közül (bővebben Id. [2] [3]).

Az online és offline reklámok közötti egyik fontos különbség, hogy az interneten az ügyfelek és a reklámok, illetve hirdetök között kétirányú kommunikációs folyamat bontakozhat ki. A reklámozók meg szeretnék ismertetni a potenciális fogyasztókat termékeikkel, hogy ezáltal többet vásároljanak tölük. Ez a folyamat sokkal hatékonyabb az interneten, mivel itt a fogyasztók alaposabban megismerhetik, esetenként ki is próbálhatják a terméket. Ha a fogyasztó többet szeretne tudni egy termékről, rákattint a hirdetésre, sőt, általában meg is vásárolhatja azt. Az internet tehát egyaránt megkönnyíti az információszerzési és vásárlási döntési törekvéseket, összekapcsolva ezeket.

Az online interaktív lehetőségek egy másik fontos vonatkozása, hogy a különböző internetes fórumokon a vásárlók véleményt is mondhatnak a termékekről, vagy akár szakértői értékelésekből is informálódhatnak. A tudatosabb gyártók és forgalmazók nyilvános fórumokat hoznak létre az ügyfelek véleményeinek közzétételére. Mivel a hirdetőknek érdekükben áll minden olyan információt közzétenni, amelyek a potenciális ügyfeleket érdeklik, rendszerint honlapjukon lehetővé teszik a termékekkel és szolgáltatásokkal kapcsolatos érdeklődést és segítséget nyújtanak a megfelelő termék kiválasztásához. Így nem csak a reklámozó beszél a fogyasztókhoz, hanem ők is beszélnek a reklámozóhoz, ami hatalmat ad a felhasználók kezébe, megváltoztatva a termelő-vásárló kapcsolat jellegét. Többek között ezért nevezi Sas István - Pratkanis és Aronson „rábeszélögép” fogalmából kiindulva - a „visszabeszélőgép” korszakának a reklámkészítés jelenkorát [4] [5].

Mivel a hirdetésre kattintva számos információ a fogyasztó rendelkezésére áll, tulajdonképpen megszünik a hagyományos (vagy offline) reklámok egy költséges problémája, amit röviden tér-idő korlátnak nevezhetünk. Egy TV reklám általában 10-30 másodperc (vagy kevesebb), az újságokban hirdetésre alkalmas felületek ára is exponenciálisan növekszik a terület árának növekedésével. Ez jelentősen korlátozza a közölhető információ mennyiségét. Az online reklámfelületekre kattintva az érdeklődő olvasó rendszerint a hirdető oldalára kerül, ahol minden releváns információt megkaphat a termékkel kapcsolatban. Az online reklámok közzétételi ideje is sokkal kevésbé költséges, mint a hagyományos reklámoké. Ezért az online reklámhordozók esetében tulajdonképpen nem áll fenn a tér-idő korlát [2].

Egy másik, talán a legfontosabb különbség a mérhetöség, vagy nyomon követhetöség területén van. Míg a hagyományos reklámok esetén felhasználói mintacsoportoktól vett adatok alapján történik a mérés, az interneten minden megjelenés és az ezzel kapcsolatos fogyasztói viselkedés számos paraméter mentén nyomon követhető. A hirdető pontosan megtudhatja, hogy egy bizonyos idő alatt hányan látták vagy kattintottak a hirdetésre, milyen oldalakról kiindulva jutottak el a hirdetőig (bővebben ld. [1] [3]).

További fontos különbség, hogy az internetes reklámok esetében hagyományos médiumoknál sokkal jobb pontosabban behatárolható a célpiac (vagy célközönség). A hagyományos célközönségbehatároló kategóriák pontosabb definiálása mellett új szempontokat is figyelembe lehet venni a célközönség behatárolásánál. A felhasználók adataiból, valamint a mérési adatokból nagyon pontosan behatárolhatók azok a potenciális fogyasztók, akihez érdemes eljuttatni az üzenetet [6]. 
Minden internet-felhasználót az ízlésének és érdeklődési körének megfelelő reklámokkal céloznak meg.

Milyen szerepe lehet ezeknek a különbségeknek a fogyasztói magatartás alakulása szempontjából? A továbbiakban rámutatunk a kérdés néhány megközelítésére.

\section{Változó marketingkommunikációs stratégiák}

\subsection{A reklámüzenetek pozicionálása}

A reklámozás a marketing-stratégiák promoválási tevékenységei közé tartozik, több más tevékenységgel együtt (mint a PR, személyes eladás, stb.). [7] [8] [9]. Ennek megfelelöen az STPmarketingfolyamat (Segmentation, Targeting and Positioning - piacszegmentáció, célpiac kiválasztása és pozicionálás, Id. [9]) egy keretrendszert képez a reklámüzenetek meghatározása szempontjából. A hagyományos és az online reklámok létrehozásánál is az ügyfeleket annak alapján osztjuk fel csoportokra (szegmensekre), hogy az adott termék milyen tulajdonsága lehet leginkább érdekes az adott szegmens számára [10]. Ennek alapján döntjük el, mit fogunk kiemelni a promóciós tevékenységünk - és ezen belül a reklámtevékenység - során.

A kommunikációs folyamatok szempontjából e stratégia legfontosabb része a pozícionálás (márkaépítés), amelynek célja az eladók és termékek megkülönböztető elhelyezése a fogyasztók tudatában. A marketingkommunikációs törekvések keretében a reklámok jelentős mértékben hozzájárulnak a márkaszemélyiség megteremtéséhez [4]. Egy reklám létrehozásakor fontos szempont tehát a termék* (vagy az eladó) marketingstratégiával összhangban történő pozícionálása. A pozicionálás a kívánt termékimázs kialakításához szükséges információk kommunikálásán alapszik.

A pozicionálás egyik fontos feladata, hogy megkülönböztesse a terméket az alapján, hogy mit ígér az illető termék a fogyasztónak. A vásárló számára egyértelmű legyen, milyen pozíciót kíván termékünk vagy szervezetünk képviselni az adott piacon [11]. Ezért a márkák által közvetített értékek világosak kell legyenek, valamint megkülönböztethetőek a versenytársak üzenetétöl. Az egyedi pozíció kialakítását segíti az egyedi ígéret közvetítése, olyasminek az ígérete, amit a konkurens termékek nem adhatnak.

A termék egyedi pozicionálása több szempont alapján történhet, pl. terméktulajdonság alapján (a termék egy kiemelkedő tulajdonságát hangsúlyozzuk); felhasználás alapján (egyedi felhasználási terület vagy mód); fogyasztói kör alapján (egy bizonyos csoport igényeit elégíti ki); ár/érték alapján (abban egyedi, hogy az adott árkategóriában milyen minőséget ajánl). Amennyiben a terméket a tulajdonságai alapján különböztetjük meg, egyedi eladási pozícióról, vagy USP-pozícionálásról beszélünk (Unique Selling Proposition) [12]. Ezt alapvetően a marketing-szakértők határozzák meg [13].

A marketingkommunikációs tevékenységek tervezésekor legalább az egyik pozicionálási szempontot figyelembe kell venni, de az a legjobb, ha minél több szempontot bevonunk az egyedi pozíció kialakításába, oly módon, hogy ezek egymást kiegészítve hozzásegítsék a fogyasztót, hogy egységes képet alakítson ki a termékröl. Egy hordozható számítógépnek pl. lehet hosszú üzemideje (terméktulajdonság alapján történő pozicionálás), nagy memóriája, jó grafikus kártyája (video szerkesztésre is használható - megkülönböztetés felhasználási terület alapján), nők által kedvelt színekben kapható (fogyasztói kör), illetve kedvező az ára (ár/érték arány alapján történő megkülönböztetés).

A technológia fejlődésével és a termékek számának növekedésével a nagyon sok egymásra hasonlító termék van, amelyek ugyanazokat az elönyöket nyújtják. Egyre kevesebb megkülönböztetésre alkalmas termékelöny van. Ezért egyre nehezebb úgy azonosítani a termékeket egyedi terméktulajdonság, felhasználási terület, fogyasztói kör vagy ár/érték arány alapján, hogy a konkurens termékektöl megkülönböztessük.

A termékek azonosítására szolgáló objektív tulajdonságokat viszont egy egyedi reklámötlettel is lehet helyettesíteni. Az egyedi pozíció kialakitásához ezért a promoválási szakemberek egyre

\footnotetext{
* A továbbiakban bár az egyszerüség kedvéért csak termékekről beszélek, a megállapítások általában egyaránt vonatkozhatnak a szolgáltatások, márkák, szervezetek reklámozására is.
} 
gyakrabban egyedi reklámozási- és emocionális pozíciókat (is) (tulajdonképpen egyfajta mesterségesen létrehozott tulajdonságokat) rendelnek a termékekhez. A reklámok a terméktulajdonságok hangsúlyozását egyre inkább kiegészítik egyedi reklámozási és emocionális pozíció kialakítását segítő elemekkel, amelyek alapja a reklámötlet [4]. Amennyiben a termék egyediségére elsősorban marketingkommunikációs eszközökkel mutatunk rá, egyedi reklámozási, vagy UAP-pozícionálásról beszélünk (Unique Advertising Proposition) [12]. Ez azt jelenti, hogy a pozicionálást támogató kommunikációs folyamatban a sajátos termékelönyök stb. helyett egyedi reklámötleteket társítanak a termékhez (pl. Lila tehén - Milka), vagy pedig egyedi életérzést, érzelmeket (pl. Haverok, buli - Fanta). Utóbbi esetben UEP-ről (Unique Emotional Proposition) beszélünk. Laptopunk reklámozásához például felhasználhatunk egy reklámfigurát (pl. zsiráf jelenik meg minden reklámképen), vagy egy asszociálhatjuk egy érzelemmel, életérzéssel (a mozgás szabadsága). A racionális érvelés a reklámok esetében egyre inkább háttérbe kerül, a termékelőnyök felsorolása ugyanis hatástalan. A főútról az érzelmi alapú mellékutakra került a reklám lételeme. A funkcionális pozicionálásról átkerült a hangsúly az érzelmi pozícionálásra, az USP-t felváltotta az UAP és UEP [4].

$A z$ egyedi reklámozási és emocionális pozíció alapú reklámok előtérbe kerülésének a hagyományos reklámfelületeken van két további oka. Az egyik az, hogy a termékek egyre bonyolultabbá és hasonlóvá válásával az egyedi termékjellemzők leírása egyre több magyarázatot igényel. A hagyományos reklámhordozó felületek mivel térben is időben korlátozottak, nagyon kevés információt tudnak továbbítani, ami korlátozza az áruismereti paraméterek részletezését. Az UAP marketingstratégiára épülő reklámok esetében kevesebb szóval (ezért kisebb reklámfelületen) is megvalósítható a termék megkülönböztetése; a mellékutak alkalmazása tehát csökkenti annak a szükségességét, hogy az áru előnyeit bonyolultan, hosszan és drága felületeken magyarázzák [4].

Az UAP-stratégiák előtérbe kerülésének másik oka az, hogy a túl sok információ növeli a fogyasztók ellenállását a reklámokkal szemben, főként a számukra érdektelen termékek esetében. $\mathrm{Az}$ információ túlterhelés tudatos reklámkerülést vált ki [4]. Minél több olyan termék esetében találkozik a fogyasztó olyan információkat adó hirdetésekkel, amelyek nem érdeklik, annál inkább elkerüli a reklámokat (ld. alább). Ebből a szempontból is előnyösebb az UAP pozícionálásra építő reklámok használata a hagyományos reklámfelületek esetében az USP-alapú megkülönböztetéssel szemben. Az UAP megkülönböztetésre építő reklámok kevesebb információt tartalmaznak a termékröl, esetükben hangsúlyosabb szerepet kap az érzelmi ráhatás és a mellékutak felhasználása.

\subsection{USP-alapú megkülönböztetés az online reklámokban}

A fogyasztók motiváltak a termékekröl való információszerzésre - különösen a nagyobb befektetést igénylö termékek (pl. autó, nyaralás), illetve a gyakran használt termékek esetén (élelem, fogkrém, mosópor). Alapvetően tehát a potenciális ügyfelek nyitottak minden informáló jellegü forrásra, köztük a reklámok befogadására is.

Ezzel szemben egyre gyakrabban megfigyelhető a reklámok elkerülésére utaló magatartás. A reklámkerülés jelenségére az 1990-es évek közepén kezdtek felfigyelni. Egy 2003-ban közölt felmérés eredményei szerint az elutasító kategóriába tartozó fogyasztók (akik kikerülhetetlennek és manipulatívnak tartják a reklámokat) valamint a tartózkodók csoportja (akik nem szeretik, de nem is kerülik különösebben a reklámokat) a lakosság körülbelül 65\%-át teszik ki [4].

A reklámkerülésnek számos oka van: információdús világban élünk, ezért az újabb információk befogadása már fárasztó; másfelöl nincs is időnk minden információ befogadására. Súlyosbítja a reklámkerülési viselkedést, hogy számos olyan termék reklámozása rabolja az időnket és energiánkat, amelyek megvásárlásában nem vagyunk érdekeltek. Mivel a hagyományos reklámok egyoldalúan mutatják be a termékeket, és gyakran nem adnak releváns információkat ezekröl (csak érzelmileg próbálnak hatni) a reklámozás, mint kommunikációs forma hitelét veszítette. $A$ reklám kényszerüen egy dicsérő műfaj - ami ellenállást fejt ki. Nem lehet valami csak jó. * A fogyasztókban spontán ellenállás fejlődik ki az egyoldalúan pozitív érvelésen alapuló befolyásolással szemben, szkepticizmussal tekintenek a reklámokra, és általában tudatosan kerülik ezeket.

\footnotetext{
* Bizonyított, hogy a közlés befogadóinak intelligenciája szerepet játszik abban, hogy az egyoldalú, vagy a kétoldalú érvelés a hatásosabb.
} 
A reklámtervezők számára ezért adott a kihívás, hogy csökkentsék a fogyasztói ellenállást: olyan reklámokat kell létrehozni, amelyek érdeklik a fogyasztókat, és amelyek számukra releváns információkat tartalmaznak. Az elöbbi célpiac-kiválasztási (targeting) és pozicionálási problémaMegfelelő célzással és pozícionálással csak azokhoz a személyekhez jutnak el a reklámüzenetek, amelyek nagy valószínüséggel érdeklődnek a hirdetett termék iránt. A digitális világban számos lehetőség arra, hogy egyrészt ezeket a személyeket azonosítsuk, másrészt hogy csakis nekik juttassuk el az üzeneteket [1]. Mivel minden fogyasztónak azokat a termékeket reklámozzuk, amelyeknek a megvásárlása iránt érdeklődik, nagyobb lesz az online reklámok hatékonyságát mérő átkattintási arány, és hosszú távon várhatóan csökken a reklámkerülő viselkedés.

A releváns információk közlése marketingkommunikációs kihívás. A nagyobb beruházások elött a vásárlók szeretnének minél többet megtudni a termékröl. A részletesebb termékinformációk ezért szükségszerü az internetes reklámozás minden formája esetében. Akkor tudunk egy márkát hitelesen bemutatni, ha a hozzá kapcsolódó információk szorosan kötődnek hozzá [1]. Ezért egyre fontosabb odafigyelni arra, hogy mit akar a fogyasztó. A szervezetek (különösen a kereskedelmi szervezetek) mindig is figyeltek az ügyfeleikre, de az egyirányú tömegtájékoztatási eszközök korában a fogyasztók többnyire feltárandó demográfiai információforrások voltak. Véleményüket, attitüdjüket elsősorban fókuszcsoportok révén vizsgálták, és a megfigyeléseket általánosították az adott publikum-szegmens valamennyi képviselőjére.

Az utóbbi néhány évben a nagyobb forgalmazók és a média egyre több képviselője hangoztatja, hogy jelentősen megváltozott az fogyasztók szemléletmódja és viszonyulása a márkákkal szemben. Az internet segítségével fogyasztók hatásos eszközt kaptak a kezükbe véleményük közlésére, amellyel fogyasztók tömegeinek befolyásolhatják az attitűdjét. Omid Kordestani, a Google kereskedelmi aligazgatója szerint a fogyasztók ilyen hatalma alapvetően befolyásolja a marketingtevékenységek minden vonatkozását [3].

Kimeríthetetlen vizsgálati kérdés, hogy milyen reklámot néz meg szívesen a fogyasztó - ez koronként és kultúránként változó. Az, hogy az online felületen a felhasználó a reklámot általában kikapcsolhatja, létfontosságúvá teszi a fogyasztói igényekre való odafigyelést. Nem csak annak a vizsgálatáról van szó, hogy mit vár el a fogyasztó a terméktől, hanem hogy mit vár el a reklámoktól.

Vollmer és Precourt szerint a XXI századi marketing-és reklámszakemberek számára a legfontosabb kihívás a fogyasztók gondolkodásának, viselkedésének megismerése [3]. Ez a legfontosabb ütőkártya a konkurenciával szemben. A felhasználó lett az új főnök a médiapiacon. A fogyasztói kategóriák mechanisztikus besorolása és leírása helyett egyre többet kell találkozni, beszélgetni velük. Elsődleges szemponttá vált annak a kutatása, hogy mi teszi számára relevánssá a reklámot. A marketing és média szakembereknek újra fel kell találniuk a szakmájukat, fogyasztócentrikussá formázva azt.

Az internetes reklámok készítése szempontjából az következik, hogy azokban az esetekben, amikor lehetőség van a termékinformációk közlésére, a reklámozott termék pozicionálását ajánlott a termékinformációkat előtérbe helyező marketingstratégiákra építeni. Mivel az online reklámoknál az átkattintási lehetőségnek köszönhetően a hirdetőnek módjában áll szinte korlátlan mennyiségü információt bocsátani az érdeklődő rendelkezésére, várhatóan egyre nagyobb szerepet kapnak az USP pozicionálási stratégiára építő reklámok. Az érzelmi ráhatás vagy egyedi reklámötlet az online világban elöreláthatólag teret veszít, a termékinformációk és termékelönyök ismertetése kerülhet elötérbe. A termék egyéniség kibontakoztatása, illetve az egyedi reklámelemek és érzelmek hozzárendelése a termékhez háttérbe kerülhetnek.

\section{A fogyasztói attitüdök alakulása}

\subsection{Fogyasztói ellenállás csökkentése}

A termékelőnyöket hangsúlyozó online reklámok előtérbe kerülése azért is ajánlott (és várható), mert a vásárlók elutasítása az információkat közvetítő reklámokkal szemben kisebb, mint az UAP stratégiára alapozó reklámok esetében. A fogyasztók "megokosodtak", ami többek között olyan magatartásokban is megnyilvánul, mint a késleltetés, nem vásárlás vagy álvásárlás [14]). A reklámcégek részben az ilyen felismerések hatására tértek át a fogyasztók érzelmi manipulálására épülő figyelemfelkeltési stratégiákról a kooperatív, a fogyasztó szükségleteinek, érdeklődési körének megfelelő reklámstratégiák használatára (Id. még [15]). Bár a mellékút sokkal hatékonyabb, mint a 
főút [5], a föúton jövő információk hitelesebbek, és kevésbé ellenállók a fogyasztók ezekkel szemben.

Az információközvetítés, a funkcionális pozícionálás előtérbe kerülésével megváltozhat a fogyasztók marketingkommunikációs üzenetekhez való viszonyulása. Amennyiben a fogyasztók érzékelni fogják, hogy a reklámok nem igyekeznek „becsapni” őket, nem tartalmaznak túlzott ígéreteket, mellébeszélést, várható, hogy a reklámokkal szembeni ellenállás is hosszú távon várhatóan csökkenni fog.

A fogyasztói ellenállás csökkentésére használt egyik bevált offline technika a Sas István által helyre tevésnek nevezett eljárás [4], az őszinteség, realitás, tárgyilagosság, könnyedség segítségével. A fogyasztói ellenállást csökkenti, ha a kínált termékek jelentőségét nem növeljük kozmikus méretekre, hanem a maguk értékrendjéhez mérten kezeljük.

$A z$ online reklámok esetében erre sokkal nagyobb lehetőség van, mint a hagyományos reklámoknál. $A z$ online reklámok túlmennek azon, hogy elhitessék a vásárlóval, szüksége van a termékre. A reklámok mögött fellelhető információk (leírások, elemzések, más vásárlók véleményei) segítik a vásárlói döntés meghozatalát.

A reklámstratégiák alakulása összhangban van a promóciós tevékenységek, tágabb értelemben a szervezetek és ügyfeleik közötti kommunikáció szemléletmódjának alakulásával. A „visszabeszélőgép” korszakában a fogyasztóknak hatékony eszközeik vannak olyan kommunikációs folyamatok elindítására, amelyek befolyásolják egy termékkel kapcsolatos vélemény alakulását függetlenül attól, hogy ezek a kommunikációs folyamatok a fogyasztók között, vagy pedig a fogyasztók és a szervezet között történnek.

\subsection{Tudatos fogyasztói magatartás, kritikai gondolkodás}

A fogasztói tudatosságnak többféle értelmezése van. Egy összetett jelenségröl van szó, amely leginkább attitűdként értelmezhető [16]. A továbbiakban az önérdekekre fókuszáló tudatosságként értelmezzük a fogalmat, miszerint a fogyasztó elöre megfontolja vásárlási szempontjait, információkat gyüjt vásárlási döntése meghozatalához [17]. A tudatos fogyasztói magatartás kritikus, megfontolt gondolkodást jelent a vásárlói döntések meghozatalakor a termék minőségére, szükségességére, ár-érték arányára stb. vonatkozóan.

Az online reklámok esetén a fogyasztó számára sokkal könnyebben elérhetővé válnak a tudatos vásárlói döntés meghozatalához szükséges információk, ezért joggal feltételezhető, hogy az online reklámok hozzájárulnak egy tudatosabb fogyasztói kultúra kialakulásához. A tudatos vásárlói attitüd kialakulását az online elérhető információk egy olyan gondolkodásmód ösztönzése révén fejlesztik, amelyet a szakirodalomban a „kritikai gondolkodás” gyüjtőnév alatt ismerünk.

Kritikai gondolkodásról a véleményalkotás kontextusában beszélünk, amikor tudatosan megfontoljuk, hogy egyrészt van-e elég információnk a véleményalkotáshoz, másrészt magát a véleményalkotást is érvek alapján vezetjük le. Fontos kihangsúlyozni, hogy nem csak az igaz, hamis, stb. jellegủ vélemények alkotásának megfontolásáról van szó, hanem annak az eldöntéséről is, hogy van-e egyáltalán elegendő információnk a véleményalkotáshoz (az online információtöbblet éppen ezért segíti a tudatos véleményalkotást). Amennyiben tudatosan mérlegeljük, hogy miként reagáljunk észrevételekre, tapasztalatokra, verbális vagy írt közlésekre, vagy érvekre, akkor kritikusan gondolkodunk*. A kritikai gondolkodás során figyelembe vesszük a bizonyítékokat, a döntés kontextusát, milyen releváns kritériumok mentén hozhatunk döntést, milyen eljárások alapján hozunk döntéseket (jelen kontextusban a vásárlói döntéseket), és milyen elméleti megfontolások, illetve előzetes ismeretek szükségesek, hogy megértsük a probléma természetét. A vásárlói kritikai gondolkodás kialakulása az emberek azon motivációjára alapszik, hogy szeretnek racionális döntéseket hozni, föként az olyan kérdésekben és problémákban, amelyek jelentős mértékben meghatározhatják a jövőjüket, illetve amelynek megoldása sok időbe és energiába (pénzbe) kerülhet.

\footnotetext{
* A „kritikai” jelzőnek van egyet nem értést kifejező, negatívan bíráló konnotációja - a kritikai gondolkodás jelen értelmezésére ez nem vonatkozik.
} 
Egyre népszerübbek azok a honlapok, amelyek a termékek tesztelését, objektív jellemzését ismertetik. Ezen belül is két nagyobb kategória figyelhető meg: a profi termékelemzőké (hivatásos szakértők által készített, néha csak költség ellenében elérhető elemzések), valamint a fogyasztói véleményeké. Mindkettöre érvényes, hogy az elemzés történhet „külső befolyás” hatására is. A profi termékelemzőket például jutalmazhatja egy szervezet, ha a termékeinek bizonyos pozitiv vonatkozásait kiemeli. Hasonlóképpen, a fogyasztói értékelések között is lehetnek olyanok, amelyek egy szervezet kérésére íródtak a fogyasztói vélemények manipulálása érdekében, szakszerüen megtervezett technikákat használva, hogy hitelesnek tűnjenek. Bárhogyan is, a termékjellemzésekből és tesztekből való tájékozódás egyre népszerübb, ami mindenképpen hozzájárul a megfontoltabb fogyasztói döntéshozatalhoz.

Az online reklámok tehát sajátosságaikból adódóan hozzásegíthetik a fogyasztókat az objektív véleményalkotáshoz. Amennyiben egy reklámozott termék (vagy márka) érdekli a fogyasztót (és mivel a digitális média sokkal pontosabb célközönség-behatárolást tesz lehetővé, egyre pontosabban választhatók ki a potenciális fogyasztók), a reklámra kattintva sok információt megtudhat a termékröl.

Adott tehát a fogyasztó motivációja, hogy - amennyiben a körülmények lehetővé teszik kritikusan gondolkozzon, és az online reklámok által elérhető információk kedvezőbb feltételeket biztosítanak ehhez, mint a hagyományos reklámok. Jogosan feltételezhetjük tehát, hogy az online reklámok hozzájárulnak a tudatosabb fogyasztói magatartás kialakulásához, és ezen keresztül a fogyasztók kritikai gondolkodásának fejlesztéséhez. A pénz hatékony elköltéséröl, a pénz megszerzésében fektetett energia hatékonyabb megtérüléséről van szó - ez pedig mindenkit érzékenyen érint [18].

\section{5. Összefoglalás. Kutatásra érdemes kérdések}

Tanulmányomban azt elemeztem, hogy az online reklámok jellegzetességei milyen változásokat eredményezhetnek a reklámkészítők és fogyasztók világában. A reklámozók számára megváltoznak a megkülönböztetési stratégiák, másképpen figyelnek oda a fogyasztókra, több, és célzottabb információt adnak át.

Az online reklámok megkönnyítik a fogyasztó számára azon információk elérését amelyek érdeklik őket, segítve a vásárlói döntések meghozatalát. Következésképpen feltételezhető, hogy csökkenni fog a fogyasztók reklámokkal szembeni ellenállása. Akár meg is szünhet a hagyományos értelemben vett, visszataszító és tolakodó „reklám”, amellyel kapcsolatban a fogyasztó úgy érezte, hogy egyoldalúan mutat be információkat és befolyásolni akarja; helyette a reklám inkább a vásárlói döntést segítő információvá alakul át.

Az emocionális pozícionálásra építő, mellékutakat használó reklámok általában félrevezető, helyenként hihetetlen információkat közvetítenek a termékröl. Ez hosszú távon árt a reklámok szavahihetőségének. Több szakértő is érvel - meglehetősen eltérő szempontok alapján - az UAP stratégiákra építő reklámok „halála” mellett [19] [20] [21]. Mahajand és Wind amellett érvelnek, hogy a közölt termékinformációk spektrumának kiszélesítésével is az érzelmi ráhatást kell az elötérbe helyezni, megemlítve, hogy az információközvetítésre alapuló marketingstratégiák elötérbe kerülését nem lehet megkerülni [22]. A környezettudatos márkajegyek emocionális és funkcionális pozicionálásának összehasonlító vizsgálata alapján Hartman és mtsai [23] megállapítják, hogy a funkcionális pozicionálás esetében a kognitív jegyek fokozottabban jelennek meg a márkaészlelésben.

Nagy kihívást jelent a kutatók számára a felvetett kérdések vizsgálata. Milyen mértéken változik a fogyasztók attitűdje az online reklámok esetén? Mikor tartják vonzónak vagy taszítónak az online reklámokat? Hogyan befolyásolják az online reklámok a tudatos vásárlói magatartást? Milyen hatásmechanizmusokra alapoznak az online reklámok készitői? Hogyan befolyásolják a vélemények a vásárlói szokásokat? Hogyan válik valaki véleményvezérré? Befolyásolható-e ez a folyamat? Az online reklámok és a „visszabeszélés” lehetősége valóban segíti egy céltudatosabb és kritikusabb gondolkodásmód kialakulását? Érdekes kérdések, melyek megválaszolása izgalmas kutatási területnek ígérkezik.

\section{Irodalomjegyzék}


[1] Zeff, R., \& Aronson, B. (2000). Reklám az interneten. Budapest: Geomédia.

[2] Veghes Ruff, I., \& Grigore, B. (2003). Relaţii publice şi publicitatea online. laşi: Polirom.

[3] Vollmer, C., \& Precourt, G. (2008). Always On. Advertising, Marketing, and Media in an Era of Consumer Control. New York: McGraw Hill.

[4] Sas, I. (2006). Reklám és pszichológia. Budapest: Kommunikációs Akadémia Kft.

[5] Pratkanis, A., \& Aronson, E. (1992). A rábeszélőgép. Élni és visszaélni a meggyőzés mindennapos mesterségével. Budapest: AB OVO.

[6] Plummer, J., Rappaport, S., Hall, T., \& Barocci, R. (2007). The online advertising playbook. Proven strategies and tested tactics from the advertising research foundation. . Hoboken, New Jersey: John Wiley \& Sons, Inc.

[7] Janoschka, A. (2004). Web Advertising: New forms of communication on the Internet. Amsterdam/Philadelphia: John Benjamins Publishing Company.

[8] O'Guinn, T., Allen, C., \& Semenik, R. J. (2014). Advertising and Integrated Brand Promotion. Nelson Publication.

[9] Shaw, R., \& Mazur, L. (1997). Marketing acountability: improving business performance. London: Finantial Times Retail and Consumer Publishing.

[10] Courtland, L. B. (1995). Advertising excellence: McGraw-Hill.

[11] Stotesbury, R. (2005). Advertising creativity. In A. Mackay (Ed.), The practice of advertising (Fifth ed., pp. 118-131): Elsevier.

[12] Grünig, R., \& Kühn, R. (2008). Process-based strategic planning (Fifth ed.). Berlin: Springer.

[13] Sengupta, S. (2005). Brand positioning. Strategies for competitive advantage. (Second ed.). New Delhi: Tata McGraw-HIII.

[14] Törőcsik, M. (2016). A fogyasztói magatartás új tendenciái. Vezetéstudomány-Budapest Management Review, 47(4), 19-25.

[15] Molnár, E. (2016). A reklámozás mint társadalmi kommunikáció. Gradus, 3(2), 278-283.

[16] Szücs, R. S. (2017). A tudatos vásárló mítosza. Gradus, 7(2), 514-521.

[17] Dudás, K. (2011). A tudatos fogyasztói magatartás dimenziói. Vezetéstudomány-Budapest Management Review, 42(7-8), 47-55.

[18] Sutherland, M. (2008). Advertising and the mind of the consumer. What works, what doesn't and why. (Revised 3rd International ed.). Crows Nest: Allen \& Unwin.

[19] Ries, A., \& Ries, L. (2005). A PR tündöklése, a reklám bukása. Budapest: Geomédia kiadó Rt.

[20] Toscani, O. (1999). Reklám, te mosolygó hulla. Budapest: Park kiadó.

[21] Zyman, S., \& Brott, A. (2002). The end of advertising as we know it. Hoboken, New Jersey: John Wiley \& Sons, Inc.

[22] Mahajan, V. and Y. Wind (2002). Got emotional product positioning?. Marketing Management 11(3): 36.

[23] Hartmann, P., Ibáñez, V. A., \& Sainz, F. J. F. (2005). Green branding effects on attitude: functional versus emotional positioning strategies. Marketing intelligence \& planning. 